Published in final edited form as:

Clin Gastroenterol Hepatol. 2017 January ; 15(1): 5-12. doi:10.1016/j.cgh.2016.08.047.

\title{
Medical Management of Severe Alcoholic Hepatitis
}

\author{
Mack C. Mitchell, MD and Craig J. McClain, MD
}

\section{Importance of Alcoholic Hepatitis in Clinical Practice}

Acute alcoholic hepatitis (AH) is a serious form of acute decompensation of alcoholic liver disease (ALD) that develops in heavy drinkers and is characterized by rapid onset of jaundice, malaise, anorexia, tender hepatomegaly, and features of the systemic inflammatory response syndrome (SIRS). Two recent studies suggest the number of patients hospitalized in the U.S. with AH increased during the first decade of the 21st century $(1,2)$. Although in its most severe form, AH has a high short-term mortality rate if untreated, in 2011, only $28 \%$ of more than 1,600 patients admitted to U.S. hospitals were treated with glucocorticoids and $17 \%$ with pentoxifylline (PTX), suggesting a lack of widespread confidence in the 2 most frequently used therapies for AH (2). Patients with AH are systemically ill with a high risk of nutritional deficiency, infection, acute kidney injury (AKI), and development of multiorgan failure (MOF) syndrome(3). Recognition of the possible complications and improved understanding of the basic mechanisms of liver injury from alcohol is essential to improve clinical outcomes for patients with severe AH.

\section{Definition of Alcoholic Hepatitis}

Histologic features of $\mathrm{AH}$ include steatosis and ballooning degeneration of hepatocytes (steatohepatitis), intrahepatic cholestasis (bilirubinostasis), chicken-wire fibrosis, MalloryDenk bodies, and megamitochondria. Cirrhosis is present in the vast majority of those who are severely ill(4-6).

A recent consensus statement from the Alcoholic Hepatitis Consortium sponsored by the National Institute of Alcohol Abuse and Alcoholism (NIAAA) provided a working definition of $\mathrm{AH}$ that includes onset of jaundice within 60 days of heavy consumption (> 50 $\mathrm{g} /$ day) of alcohol for a minimum of 6 months, a serum bilirubin $>3 \mathrm{mg} / \mathrm{dL}$, an elevated AST (50-400 U/L), an AST:ALT ratio > 1.5, and no other obvious cause for hepatitis (6). The consensus statement proposed classifying patients with $\mathrm{AH}$ as definite when a liver biopsy was used to establish the diagnosis; probable when the clinical and laboratory features were present without potential confounding problems; and possible when confounding problems were present. This proposed classification is intended to improve interpretation of future

Address correspondence to: Mack C. Mitchell, MD, Chief Medical Officer Southwestern Health Resources, Professor and ViceChairman Internal Medicine, U.T. Southwestern Medical Center, 5323 Harry Hines Blvd., Dallas, TX 75390,

Mack.Mitchell@utsouthwestern.edu, Phone: 214-648-5036, Fax: 214-648-5607.

Publisher's Disclaimer: This is a PDF file of an unedited manuscript that has been accepted for publication. As a service to our customers we are providing this early version of the manuscript. The manuscript will undergo copyediting, typesetting, and review of the resulting proof before it is published in its final citable form. Please note that during the production process errors may be discovered which could affect the content, and all legal disclaimers that apply to the journal pertain. 
treatment trials in patients with $\mathrm{AH}$, since prior studies indicated that $10-15 \%$ of subjects diagnosed with acute AH based on clinical criteria alone did not have characteristic histologic features on a liver biopsy specimen.

\section{Risk Factors}

While the exact pathogenesis of $\mathrm{AH}$ remains a subject of active investigation, several risk factors have been identified, including female gender, elevated body-mass index (BMI), and genetic risk factors such as having the G allele of PNPLA3 (patatin-like phospholipase domain containing protein 3). Because elevated BMI is a risk factor for both $\mathrm{AH}$ and nonalcoholic steatohepatitis (NASH), distinguishing these 2 entities usually rests on the amount of alcohol consumed and the rapid onset of jaundice (7). Some experts believe that the distinction may be artificial since pre-existing fatty liver due to obesity and the metabolic syndrome could provide the necessary background for additional injury due to alcohol.

\section{The Role of Inflammation in AH}

AH is by its definition an inflammatory condition that is often accompanied by features of SIRS: tachycardia, tachypnea, fever and leukocytosis. Infections are common and must be identified and treated in patients with AH, but SIRS may develop in the absence of infection. The presence of SIRS increases the risk of developing MOF that predicts high mortality in AH (3). Numerous basic and translational studies have identified high levels of proinflammatory cytokines in patients with AH that may be linked to an increased risk of mortality.

\section{Predicting Prognosis in $\mathrm{AH}$}

In 1977, Maddrey and colleagues used the serum bilirubin and prothrombin time to define a group of patients with AH that had a 28-day mortality rate above 50\%. This formula, known as the Maddrey Discriminant Function (MDF), was subsequently used to stratify subjects for inclusion into clinical trials (8). Early trials and a subsequent randomized multicenter trial indicated that only those patients with more severe manifestations of AH and an MDF > 32 benefited from treatment with glucocorticoids $(8,9)$. The MELD score was also shown to predict 28-day and 90-day mortality, and the ABIC score (age, bilirubin, INR, and creatinine) and the Glasgow AH Score also predict 90-day mortality (10-12). All of these scoring systems have been validated to predict severe outcomes with a high degree of reliability.

Although an MDF > 32 initially defined a group of patients with a 28-day mortality rate > $50 \%$, the short-term mortality in the placebo group in recent studies (STOPAH) is much better (17\%) than the mortality rate in the U.S. multicenter trial (35\%), likely because of improvements in best supportive care (BSC)(13) (see later). Importantly, improved outcome with BSC alone makes direct comparisons with historical data from trials more difficult since the time when the trials were completed must be considered.

The Lille score uses data obtained from the first week of treatment with prednisolone to predict whether an individual patient is likely to have a favorable outcome (14). This 
information is important since prolonged use of glucocorticoids is associated with an increased risk of infection in patients with AH (13). Combining the Lille model with the MELD score has been proposed as a further refinement (15).

\section{Mechanisms of Action of Current AH Therapy}

AH is an inflammatory disease, and proinflammatory mediators, such as tumor necrosis factor (TNF), play a critical role in liver injury. Gut-derived toxins such as lipopolysaccharides (LPS) have been postulated to translocate across a leaky gut barrier and bind to Toll-like receptors with subsequent proinflammatory cytokine production. The two most widely used drug therapies for severe AH both have anti-inflammatory mechanisms of action.

Glucocorticoids, considered the standard of care for severe AH by many gastroenterologists/ hepatologists and professional organizations, bind to receptors (GRs) in the cytoplasm. GRs subsequently translocate to the nucleus and bind to the glucocorticoid response elements (GREs) in the promoter regions of glucocorticoid responsive genes to switch on expression of certain anti-inflammatory genes. Glucocorticoids can also act indirectly to repress activity of a number of relevant transcription factors (e.g., nuclear factor kappa B) with subsequent down-regulation of inflammatory genes. This process requires recruitment of co-repressor molecules, particularly histone deacetylases (HDAC-6,-2) $(16,17)$.

Unfortunately, some patients are not candidates for glucocorticoid treatment and others develop glucocorticoid resistance by various molecular mechanisms $(18,19)$, which may differ between patients. For example, inhibition of interleukin 2 (IL-2), a key growth factor secreted by $\mathrm{T}$ cells that antagonizes the anti-inflammatory response to glucocorticoids, enhances glucocorticoid sensitivity in vitro (20). Levels of GR-B, an alternatively spliced form of GR that essentially acts as a dominant negative inhibitor of glucocorticoid action, are increased in some glucocorticoid-resistant disease states $(21,22)$. While our knowledge of mechanisms of glucocorticoid action and resistance has expanded, further information is needed to potentially enhance glucocorticoid effectiveness.

PTX, a relatively weak nonspecific phosphodiesterase (PDE) inhibitor has been shown to attenuate liver injury and fibrosis in animal models of liver disease $(23,24)$. Intracellular levels of cyclic adenosine monophosphate (cAMP) regulate LPS-inducible expression of TNF by monocytes/macrophages $(25,26)$. PDE inhibitors increase cAMP levels, thereby inhibiting TNF production in vivo and in vitro $(25,27-30)$. Importantly, PDE4 inhibitors have also been demonstrated to upregulate the anti-inflammtory/antifibrotic cytokine IL-10 (31-35). Recent studies have shown a pathogenic role of PDE4 enzymes in the development of cholestatic liver injury/fibrosis, and significant protection using a PDE4-specific inhibitor (36). Experimental and clinical studies provide a rationale for targeting PDE4 as a therapeutic strategy for treatment of ALD, but this has been hampered by dose-associated side effects including severe nausea, emesis, and sedative effects caused by the increased cAMP levels in the central nervous system $(25,37)$. Thus, targeting potent PDE inhibitors directly to the liver may be more effective. 


\section{Rationale for Current Therapy for Severe $\mathrm{AH}$ and Results of Randomized Controlled Trials (RCT) for Treatment of Severe AH}

More than 20 RCTs of glucocorticoids have been conducted in patients with severe AH defined by an MDF > $32(8,9,38-43)$. Several of these studies were used to create the current guidelines of the AASLD and EASL $(44,45)$. The 1989 U.S. multicenter trial of methylprednisolone vs. placebo for treating severe AH reported that the 28-day mortality rate was significantly lower in those patients treated with methylprednisolone compared with BSC (9). A subsequent trial from France reported similar findings $(38,43)$. Although some trials failed to show significant survival benefit in subjects treated with glucocorticoids, 2 separate meta-analyses that included primarily high-quality studies concluded that there is a benefit to treatment $(39,46)$, whereas a third did not (40). A 2008 Cochrane systematic review of 15 trials concluded that there was no benefit from glucocorticoids, except possibly in the group with an MDF > 32, primarily due to substantial variability in bias (41). Those trials with low bias showed benefit, whereas trials with high bias showed no benefit.

PTX was reported to reduce mortality in patients with severe AH (MDF > 32) (47). Subsequent larger trials reached similar conclusions $(48,49)$. Most of the reduction in mortality appeared to be related to a decrease in the frequency of hepatorenal syndrome (HRS) in the survivors (47). However, 2 meta-analyses of all trials concluded that there were no differences in short-term mortality related to PTX $(50,51)$. Subsequent studies combining PTX with glucocorticoids did not show any additive benefit $(42,52)$.

The largest randomized trial to date in patients with severe AH, STOPAH, enrolled 1,103 patients in the U.K. between 2011 and 2014 (13). Inclusion criteria were MDF > 32, onset of jaundice within 2 months, bilirubin $>4.7 \mathrm{mg} / \mathrm{dL}$ and AST $<500 \mathrm{U} / \mathrm{L}$, but neither liver biopsy confirmation nor a minimum elevation of the AST were required. Patients with a serum creatinine $>5.7 \mathrm{mg} / \mathrm{dL}$ were excluded. Each clinician made individual decisions regarding nutritional supplementation and use of agents such as terlipressin for hepatorenal syndrome. Patients were randomized to receive prednisolone $40 \mathrm{mg}$ (equivalent of $32 \mathrm{mg}$ methylprednisolone) daily, PTX $400 \mathrm{mg} 3$ times daily, the combination of prednisolone and PTX, or placebo daily. Results are shown in Table 1 . The odds ratio for all patients receiving prednisolone (including the combination with PTX) was 0.72 (0.52-1.01) and was not statistically significant $(\mathrm{p}=0.06)$, whereas the odds ratio for all patients receiving PTX was 1.07 (0.77-1.49). The mortality rate for 90 days was $30 \%$ and for 1 year $56 \%$, similar in all 4 groups (Table 1). There was no difference in development of AKI, but the groups treated with prednisolone had more infections (13\%) than those not treated with prednisolone (7\%) $(\mathrm{p}=.002)$.

The lower 28-day mortality rate for placebo in this study compared to other studies $(39,53)$ adversely impacted the calculated power analysis and may explain why the effects of prednisolone narrowly missed achieving statistical significance for improvement in shortterm mortality. Furthermore, treatment of AKI with agents such as terlipressin could be a confounding factor and may help explain a lack of benefit for PTX. 
Network meta-analysis allows both direct comparisons of interventions and indirect comparisons across trials using a common comparator such as placebo. Although the statistical tools and mathematical analysis are more complex, the potential advantage is that it allows comparison of interventions that may not have been compared directly against each other in trials. Using this technique, various treatments from 22 recent trials involving 2,621 patients with severe AH were compared (53). Based on moderate quality evidence, treatment with glucocorticoids alone or in combination with PTX or the anti-oxidant, $\mathrm{N}$-acetylcysteine (NAC) that is used to restore glutathione (GSH) levels in patients with acetaminophen poisoning, was shown to reduce 28-day, but not 90-day, mortality in patients with $\mathrm{AH}$. Based on lower quality evidence, PTX alone was also shown to reduce 28-day, but not 90day, mortality. The analysis included the STOPAH trial and showed that the reduction in mortality was comparable for both glucocorticoids and PTX, possibly because the STOPAH trial was not powered to detect differences among all 4 groups.

A number of potential treatments including vitamin $\mathrm{E}$ and an antioxidant cocktail including NAC have been tried with little success in severe AH $(54,55)$. However, the combination of prednisolone plus NAC given intravenously over the first 5 days of the trial resulted in the most significant improvement in 1-month mortality $(53,56)$ of the studies included in the network meta-analysis (53). The mortality rate in patients treated with prednisolone $40 \mathrm{mg}$ daily plus NAC was $8 \%$ compared with $24 \%$ for those treated with prednisolone alone (56). Patients treated with the combination had fewer infections (19\%) in 6 months than those treated with prednisolone alone $(42 \%)(p=0.001)$ and a lower incidence of HRS $(12 \%$ vs. $25 \%, \mathrm{p}=0.02)$. These important findings remain to be confirmed by additional studies.

Levels of TNF- $a$ are often elevated in patients with severe AH $(57,58)$. Although preliminary evidence suggested that anti-TNF therapy might be beneficial in severe AH (59, 60), subsequent larger trials of etanercept (antibody to TNF receptor) and the combination (anti-TNF) with glucocorticoids led to a higher risk of infections and higher mortality rate than BSC $(61,62)$. These trials have generally led to an abandonment of anti-TNF therapy in AH..

\section{Best Practice Advice for Treatment of AH (Table 2)}

Jaundice is an important clinical manifestation of decompensated ALD and is often the first indication of serious AH. Patients with underlying ALD who become jaundiced should be hospitalized to encourage abstinence and to exclude serious bacterial infections.

Abstinence remains the cornerstone of therapy for AH. Numerous studies have shown that patients who return to heavy drinking have a far worse prognosis than those who remain abstinent or have reduced alcohol consumption. Although abstinence is important at all stages, it is particularly important to emphasize abstinence beyond 90 days when many patients are regaining normal functioning. A team approach to achieve this goal is optimal.

Infection may be both a precipitating event and a factor leading to a poor outcome in $\mathrm{AH}$. Although glucocorticoids may improve short-term survival in severe $\mathrm{AH}$, the increased risk of infection leads to no change in survival at 90 days and 1 year after diagnosis $(3,53,56$, 
61-63). Infections often precede development of AKI and MOF, which has a high mortality rate $(3,64)$. A high index of suspicion is required to identify both bacterial and fungal infections in patients with $\mathrm{AH}$, since fever may not always be present and an elevated white blood cell count is an unreliable indicator of infection. The presence of SIRS on admission is a risk factor for subsequent development of MOF (3).

AKI can develop in patients with severe AH for many reasons, including infection, changes in hemodynamics particularly intravascular volume depletion, and as a consequence of nephrotoxic drugs. Administration of iodinated contrast dye is a risk factor for AKI in patients with diabetes mellitus, heart failure, and other conditions and is likely to cause similar problems in patients with cirrhosis (65).

Malnutrition is common in $\mathrm{AH}$ and impairs recovery from $\mathrm{AH}$ (66). One multicenter study indicated that enteral nutrition was comparable to glucocorticoids in reducing 28-day mortality and more effective in reducing long-term mortality (67). However, another multicenter study reported that adding enteral supplementation via nasogastric (NG) tube to glucocorticoid therapy was no more effective than glucocorticoids alone (68). This study was under-powered, and there was a higher than expected rate of NG tube complications. Importantly, nutritional intake (regardless of the arm of the study) was a major determinant of mortality, with those consuming $<21.5 \mathrm{Kcal} / \mathrm{kg} /$ day having lower survival (68). Therefore, all patients with $\mathrm{AH}$ should be encouraged to meet their nutritional goals as early as possible. Whether NG tubes should be used to provide enteral nutrition is a subject of controversy. Normal-to-high protein diets are safe and do not increase the risk of encephalopathy in patients with AH. Further studies are needed to define the role of specific micronutrients such as zinc and probiotics in management of $\mathrm{AH}(69,70)$.

Although many studies favor the use of glucocorticoids, the appropriate duration for use is a subject of controversy. If used, glucocorticoids should be discontinued in patients who fail to improve based on Lille criteria (14). Those who have a MELD score > 26 should be considered for liver transplantation, which may be life saving $(44,71,72)$. Some transplant centers have policies that require a defined period of abstinence, and all require the willingness of a patient with a history of heavy drinking to remain abstinent after transplantation. Several studies have demonstrated that the outcomes of liver transplantation in patients with $\mathrm{AH}$ are similar to those of other transplanted patients with similar MELD scores $(71,72)$. Relapse following transplantation appears to be no more frequent than it is in patients with alcoholic cirrhosis who do not have $\mathrm{AH}$.

\section{Conclusions and Gaps in Information}

$\mathrm{AH}$ is a potentially severe form of ALD with evidence of systemic inflammation that requires anti-inflammatory and supportive treatment to prevent progression and death. The Maddrey DF, MELD, ABIC, and Glasgow scoring systems all predict prognosis accurately. Nutritional deficiencies and infections are both common in patients with $\mathrm{AH}$ and require prompt recognition and treatment to prevent devastating complications such as AKI and MOF. Current anti-inflammatory therapy with glucocorticoids modestly improves short-term mortality, but this endpoint of treatment is clearly suboptimal. The 1-year mortality rate was 
$56 \%$ in the STOPAH trial, and the 4-year mortality rate from the VA Cooperative Study for patients with AH superimposed on cirrhosis was $65 \%$, worse than that for many common forms of cancers such as colon and breast (73). Both dose and duration of therapies for AH generally have been empiric. Perhaps the concept of very high, short-term bursts of glucocorticoids to induce "immune paralysis," as is used to treat lupus nephritis, should be considered. Furthermore, relatively safe drugs such as NAC or PTX could be used for a longer duration to treat ongoing hepatic inflammation, since VA Cooperative studies documented residual histologic AH after more than a year of abstinence. Combination therapy may be optimal; we have focused mainly on inflammation, but there are multiple other targets such as gut-barrier dysfunction, cell death, liver regeneration, and fibrosis. One potential reason for the high long-term mortality is a return to drinking. New treatments need to be tested, and continued support from the NIH (NIAAA Alcoholic Hepatitis Consortium) and new industry support are necessary. Potential treatments should include drugs repurposed to treat $\mathrm{AH}$ as well as drugs and approaches to decrease alcohol abuse.

\section{References}

1. Jinjuvadia R, Liangpunsakul S, Translational R. Evolving Alcoholic Hepatitis Treatment C. Trends in Alcoholic Hepatitis-related Hospitalizations, Financial Burden, and Mortality in the United States. J Clin Gastroenterol. 2015; 49(6):506-11. doi: 10.1097/MCG.0000000000000161. PubMed PMID: 25198164; PMCID: PMC4276725. [PubMed: 25198164]

2. Nguyen TA, DeShazo JP, Thacker LR, Puri P, Sanyal AJ. The Worsening Profile of Alcoholic Hepatitis in the United States. Alcoholism, clinical and experimental research. 2016 doi: 10.1111/ acer.13069. PubMed PMID: 27147285.

3. Michelena J, Altamirano J, Abraldes JG, Affo S, Morales-Ibanez O, Sancho-Bru P, Dominguez M, Garcia-Pagan JC, Fernandez J, Arroyo V, Gines P, Louvet A, Mathurin P, Mehal WZ, Caballeria J, Bataller R. Systemic inflammatory response and serum lipopolysaccharide levels predict multiple organ failure and death in alcoholic hepatitis. Hepatology. 2015; 62(3):762-72. doi: 10.1002/hep. 27779. PubMed PMID: 25761863; PMCID: PMC4549175. [PubMed: 25761863]

4. Mookerjee RP, Lackner C, Stauber R, Stadlbauer V, Deheragoda M, Aigelsreiter A, Jalan R. The role of liver biopsy in the diagnosis and prognosis of patients with acute deterioration of alcoholic cirrhosis. J Hepatol. 2011; 55(5):1103-11. doi: 10.1016/j.jhep.2011.02.021. PubMed PMID: 21376092. [PubMed: 21376092]

5. Altamirano J, Miquel R, Katoonizadeh A, Abraldes JG, Duarte-Rojo A, Louvet A, Augustin S, Mookerjee RP, Michelena J, Smyrk TC, Buob D, Leteurtre E, Rincon D, Ruiz P, Garcia-Pagan JC, Guerrero-Marquez C, Jones PD, Barritt ASt, Arroyo V, Bruguera M, Banares R, Gines P, Caballeria J, Roskams T, Nevens F, Jalan R, Mathurin P, Shah VH, Bataller R. A histologic scoring system for prognosis of patients with alcoholic hepatitis. Gastroenterology. 2014; 146(5):1231-9. e1-6. doi: 10.1053/j.gastro.2014.01.018. PubMed PMID: 24440674; PMCID: 3992184. [PubMed: 24440674]

6. Crabb DW, Bataller R, Chalasani NP, Kamath PS, Lucey M, Mathurin P, McClain C, McCullough A, Mitchell MC, Morgan TR, Nagy L, Radaeva S, Sanyal A, Shah V, Szabo G, Consortia NAH. Standard Definitions and Common Data Elements for Clinical Trials in Patients With Alcoholic Hepatitis: Recommendation From the NIAAA Alcoholic Hepatitis Consortia. Gastroenterology. 2016; 150(4):785-90. doi: 10.1053/j.gastro.2016.02.042. PubMed PMID: 26921783. [PubMed: 26921783]

7. Dunn W, Angulo P, Sanderson S, Jamil LH, Stadheim L, Rosen C, Malinchoc M, Kamath PS, Shah VH. Utility of a new model to diagnose an alcohol basis for steatohepatitis. Gastroenterology. 2006; 131(4):1057-63. doi: 10.1053/j.gastro.2006.08.020. PubMed PMID: 17030176; PMCID: PMC2483536. [PubMed: 17030176]

8. Maddrey WC, Boitnott JK, Bedine MS, Weber FL Jr. Mezey E, White RI Jr. Corticosteroid therapy of alcoholic hepatitis. Gastroenterology. 1978; 75(2):193-9. PubMed PMID: 352788. [PubMed: $352788]$ 
9. Carithers JRL, Herlong HF, Diehl AM, Shaw EW, Combes B, Fallon HJ, Maddrey WC. Methylprednisolone Therapy in Patients with Severe Alcoholic HepatitisA Randomized Multicenter Trial. Annals of Internal Medicine. 1989; 110(9):685-90. doi: 10.7326/0003-4819-110-9-685. [PubMed: 2648927]

10. Dunn W, Jamil LH, Brown LS, Wiesner RH, Kim WR, Menon KV, Malinchoc M, Kamath PS, Shah V. MELD accurately predicts mortality in patients with alcoholic hepatitis. Hepatology. 2005; 41(2):353-8. doi: 10.1002/hep.20503. PubMed PMID: 15660383. [PubMed: 15660383]

11. Dominguez M, Rincon D, Abraldes JG, Miquel R, Colmenero J, Bellot P, Garcia-Pagan JC, Fernandez R, Moreno M, Banares R, Arroyo V, Caballeria J, Gines P, Bataller R. A new scoring system for prognostic stratification of patients with alcoholic hepatitis. The American journal of gastroenterology. 2008; 103(11):2747-56. doi: 10.1111/j.1572-0241.2008.02104.x. PubMed PMID: 18721242. [PubMed: 18721242]

12. Forrest EH, Morris AJ, Stewart S, Phillips M, Oo YH, Fisher NC, Haydon G, O'Grady J, Day CP. The Glasgow alcoholic hepatitis score identifies patients who may benefit from corticosteroids. Gut. 2007; 56(12):1743-6. doi: 10.1136/gut.2006.099226. PubMed PMID: 17627961; PMCID: 2095721. [PubMed: 17627961]

13. Thursz MR, Richardson P, Allison M, Austin A, Bowers M, Day CP, Downs N, Gleeson D, MacGilchrist A, Grant A, Hood S, Masson S, McCune A, Mellor J, O'Grady J, Patch D, Ratcliffe I, Roderick P, Stanton L, Vergis N, Wright M, Ryder S, Forrest EH, Trial S. Prednisolone or pentoxifylline for alcoholic hepatitis. The New England journal of medicine. 2015; 372(17):161928. doi: 10.1056/NEJMoa1412278. PubMed PMID: 25901427. [PubMed: 25901427]

14. Louvet A, Naveau S, Abdelnour M, Ramond MJ, Diaz E, Fartoux L, Dharancy S, Texier F, Hollebecque A, Serfaty L, Boleslawski E, Deltenre P, Canva V, Pruvot FR, Mathurin P. The Lille model: a new tool for therapeutic strategy in patients with severe alcoholic hepatitis treated with steroids. Hepatology. 2007; 45(6):1348-54. doi: 10.1002/hep.21607. PubMed PMID: 17518367. [PubMed: 17518367]

15. Louvet A, Labreuche J, Artru F, Boursier J, Kim DJ, O'Grady J, Trepo E, Nahon P, Ganne-Carrie N, Naveau S, Diaz E, Gustot T, Lassailly G, Cannesson-Leroy A, Canva-Delcambre V, Dharancy S, Park SH, Moreno C, Morgan TR, Duhamel A, Mathurin P. Combining Data From Liver Disease Scoring Systems Better Predicts Outcomes of Patients With Alcoholic Hepatitis. Gastroenterology. 2015; 149(2):398-406. e8. quiz e16-7. doi: 10.1053/j.gastro.2015.04.044. PubMed PMID: 25935634. [PubMed: 25935634]

16. De Bosscher K, Haegeman G. Minireview: latest perspectives on antiinflammatory actions of glucocorticoids. Mol Endocrinol. 2009; 23(3):281-91. Epub 2008/12/20. doi: 10.1210/me. 2008-0283. PubMed PMID: 19095768. [PubMed: 19095768]

17. Barnes PJ, Adcock IM. Glucocorticoid resistance in inflammatory diseases. Lancet. 2009; 373(9678):1905-17. Epub 2009/06/02. doi: 10.1016/S0140-6736(09)60326-3. PubMed PMID: 19482216. [PubMed: 19482216]

18. Ito K, Chung KF, Adcock IM. Update on glucocorticoid action and resistance. The Journal of allergy and clinical immunology. 2006; 117(3):522-43. Epub 2006/03/09. doi: 10.1016/j.jaci. 2006.01.032. PubMed PMID: 16522450. [PubMed: 16522450]

19. Ito K, Yamamura S, Essilfie-Quaye S, Cosio B, Ito M, Barnes PJ, Adcock IM. Histone deacetylase 2-mediated deacetylation of the glucocorticoid receptor enables NF-kappaB suppression. The Journal of experimental medicine. 2006; 203(1):7-13. Epub 2005/12/29. doi: 10.1084/jem. 20050466. PubMed PMID: 16380507; PMCID: 2118081. [PubMed: 16380507]

20. di Mambro AJ, Parker R, McCune A, Gordon F, Dayan CM, Collins P. In vitro steroid resistance correlates with outcome in severe alcoholic hepatitis. Hepatology. 2011; 53(4):1316-22. Epub 2011/03/15. doi: 10.1002/hep.24159. PubMed PMID: 21400552. [PubMed: 21400552]

21. Barnes PJ. Mechanisms and resistance in glucocorticoid control of inflammation. The Journal of steroid biochemistry and molecular biology. 2010; 120(2-3):76-85. Epub 2010/03/02. doi: 10.1016/j.jsbmb.2010.02.018. PubMed PMID: 20188830. [PubMed: 20188830]

22. Rogatsky I, Ivashkiv LB. Glucocorticoid modulation of cytokine signaling. Tissue antigens. 2006; 68(1):1-12. Epub 2006/06/16. doi: 10.1111/j.1399-00392006.00599.x. PubMed PMID: 16774534. [PubMed: 16774534] 
23. Kucuktulu U, Alhan E, Tekelioglu Y, Ozekin A. The effects of pentoxifylline on liver regeneration after portal vein ligation in rats. Liver international : official journal of the International Association for the Study of the Liver. 2007; 27(2):274-9. doi: 10.1111/j.

1478-3231.2006.01419.x. PubMed PMID: 17311624. [PubMed: 17311624]

24. Raetsch C, Jia JD, Boigk G, Bauer M, Hahn EG, Riecken EO, Schuppan D. Pentoxifylline downregulates profibrogenic cytokines and procollagen I expression in rat secondary biliary fibrosis. Gut. 2002; 50(2):241-7. PubMed PMID: 11788567; PMCID: 1773098. [PubMed: 11788567]

25. Spina D. PDE4 inhibitors: current status. British journal of pharmacology. 2008; 155(3):308-15. doi: 10.1038/bjp.2008.307. PubMed PMID: 18660825; PMCID: 2567892.

26. Gobejishvili L, Barve S, Joshi-Barve S, Uriarte S, Song Z, McClain C. Chronic ethanol-mediated decrease in cAMP primes macrophages to enhanced LPS-inducible NF-kappaB activity and TNF expression: relevance to alcoholic liver disease. American journal of physiology Gastrointestinal and liver physiology. 2006; 291(4):G681-8. doi: 10.1152/ajpgi.00098.2006. PubMed PMID: 16751174. [PubMed: 16751174]

27. Gobejishvili L, Barve S, Joshi-Barve S, McClain C. Enhanced PDE4B expression augments LPSinducible TNF expression in ethanol-primed monocytes: relevance to alcoholic liver disease. American journal of physiology Gastrointestinal and liver physiology. 2008; 295(4):G718-24. doi: 10.1152/ajpgi.90232.2008. PubMed PMID: 18687753; PMCID: 2575909. [PubMed: 18687753]

28. Essayan DM. Cyclic nucleotide phosphodiesterases. The Journal of allergy and clinical immunology. 2001; 108(5):671-80. doi: 10.1067/mai.2001.119555. PubMed PMID: 11692087. [PubMed: 11692087]

29. Kwak HJ, Song JS, No ZS, Song JH, Yang SD, Cheon HG. The inhibitory effects of roflumilast on lipopolysaccharide-induced nitric oxide production in RAW264.7 cells are mediated by heme oxygenase- 1 and its product carbon monoxide. Inflammation research : official journal of the European Histamine Research Society [et al]. 2005; 54(12):508-13. doi: 10.1007/ s00011-005-1386-1. PubMed PMID: 16389572.

30. Ouagued M, Martin-Chouly CA, Brinchault G, Leportier-Comoy C, Depince A, Bertrand C, Lagente V, Belleguic C, Pruniaux MP. The novel phosphodiesterase 4 inhibitor, CI-1044, inhibits LPS-induced TNF-alpha production in whole blood from COPD patients. Pulmonary pharmacology \& therapeutics. 2005; 18(1):49-54. doi: 10.1016/j.pupt.2004.09.031. PubMed PMID: 15607127. [PubMed: 15607127]

31. Le Moine O, Marchant A, De Groote D, Azar C, Goldman M, Deviere J. Role of defective monocyte interleukin-10 release in tumor necrosis factor-alpha overproduction in alcoholics cirrhosis. Hepatology. 1995; 22(5):1436-9. PubMed PMID: 7590660. [PubMed: 7590660]

32. Platzer C, Fritsch E, Elsner T, Lehmann MH, Volk HD, Prosch S. Cyclic adenosine monophosphate-responsive elements are involved in the transcriptional activation of the human IL-10 gene in monocytic cells. European journal of immunology. 1999; 29(10):3098-104. doi: 10.1002/(SICI)1521-4141(199910)29:10<3098::AID-IMMU3098>3.0.CO;2-H. PubMed PMID: 10540320. [PubMed: 10540320]

33. Eigler A, Siegmund B, Emmerich U, Baumann KH, Hartmann G, Endres S. Anti-inflammatory activities of cAMP-elevating agents: enhancement of IL-10 synthesis and concurrent suppression of TNF production. Journal of leukocyte biology. 1998; 63(1):101-7. PubMed PMID: 9469479. [PubMed: 9469479]

34. Verghese MW, McConnell RT, Strickland AB, Gooding RC, Stimpson SA, Yarnall DP, Taylor JD, Furdon PJ. Differential regulation of human monocyte-derived TNF alpha and IL-1 beta by type IV cAMP-phosphodiesterase (cAMP-PDE) inhibitors. The Journal of pharmacology and experimental therapeutics. 1995; 272(3):1313-20. PubMed PMID: 7891349. [PubMed: 7891349]

35. Kambayashi T, Jacob CO, Zhou D, Mazurek N, Fong M, Strassmann G. Cyclic nucleotide phosphodiesterase type IV participates in the regulation of IL-10 and in the subsequent inhibition of TNF-alpha and IL-6 release by endotoxin-stimulated macrophages. Journal of immunology. 1995; 155(10):4909-16. PubMed PMID: 7594495.

36. Gobejishvili L, Barve S, Breitkopf-Heinlein K, Li Y, Zhang J, Avila DV, Dooley S, McClain CJ. Rolipram attenuates bile duct ligation-induced liver injury in rats: a potential pathogenic role of 
PDE4. The Journal of pharmacology and experimental therapeutics. 2013; 347(1):80-90. doi: 10.1124/jpet.113.204933. PubMed PMID: 23887098; PMCID: 3781411. [PubMed: 23887098]

37. Fleischhacker WW, Hinterhuber H, Bauer H, Pflug B, Berner P, Simhandl C, Wolf R, Gerlach W, Jaklitsch H, Sastre-y-Hernandez M, et al. A multicenter double-blind study of three different doses of the new cAMP-phosphodiesterase inhibitor rolipram in patients with major depressive disorder. Neuropsychobiology. 1992; 26(1-2):59-64. doi: 118897. PubMed PMID: 1475038. [PubMed: 1475038]

38. Mathurin P, Duchatelle V, Ramond MJ, Degott C, Bedossa P, Erlinger S, Benhamou JP, Chaput JC, Rueff B, Poynard T. Survival and prognostic factors in patients with severe alcoholic hepatitis treated with prednisolone. Gastroenterology. 1996; 110(6):1847-53. PubMed PMID: 8964410. [PubMed: 8964410]

39. Mathurin P, O'Grady J, Carithers RL, Phillips M, Louvet A, Mendenhall CL, Ramond MJ, Naveau S, Maddrey WC, Morgan TR. Corticosteroids improve short-term survival in patients with severe alcoholic hepatitis: meta-analysis of individual patient data. Gut. 2011; 60(2):255-60. doi: 10.1136/gut.2010.224097. PubMed PMID: 20940288. [PubMed: 20940288]

40. Christensen E, Gluud C. Glucocorticosteroids are not effective in alcoholic hepatitis. The American journal of gastroenterology. 1999; 94(10):3065-6. doi: 10.1111/j. 1572-0241.1999.03065.x. PubMed PMID: 10520874. [PubMed: 10520874]

41. Rambaldi A, Saconato HH, Christensen E, Thorlund K, Wetterslev J, Gluud C. Systematic review: glucocorticosteroids for alcoholic hepatitis--a Cochrane Hepato-Biliary Group systematic review with meta-analyses and trial sequential analyses of randomized clinical trials. Aliment Pharmacol Ther. 2008; 27(12):1167-78. doi: 10.1111/j.1365-2036.2008.03685.x. PubMed PMID: 18363896. [PubMed: 18363896]

42. Mathurin P, Louvet A, Duhamel A, Nahon P, Carbonell N, Boursier J, Anty R, Diaz E, Thabut D, Moirand R, Lebrec D, Moreno C, Talbodec N, Paupard T, Naveau S, Silvain C, Pageaux GP, Sobesky R, Canva-Delcambre V, Dharancy S, Salleron J, Dao T. Prednisolone with vs without pentoxifylline and survival of patients with severe alcoholic hepatitis: a randomized clinical trial. JAMA. 2013; 310(10):1033-41. doi: 10.1001/jama.2013.276300. PubMed PMID: 24026598. [PubMed: 24026598]

43. Ramond MJ, Poynard T, Rueff B, Mathurin P, Theodore C, Chaput JC, Benhamou JP. A randomized trial of prednisolone in patients with severe alcoholic hepatitis. The New England journal of medicine. 1992; 326(8):507-12. doi: 10.1056/NEJM199202203260802. PubMed PMID: 1531090. [PubMed: 1531090]

44. O'Shea RS, Dasarathy S, McCullough AJ, Practice Guideline Committee of the American Association for the Study of Liver D. Practice Parameters Committee of the American College of G. Alcoholic liver disease. Hepatology. 2010; 51(1):307-28. doi: 10.1002/hep.23258. PubMed PMID: 20034030. [PubMed: 20034030]

45. European Association for the Study of L. EASL clinical practical guidelines: management of alcoholic liver disease. J Hepatol. 2012; 57(2):399-420. doi: 10.1016/j.jhep.2012.04.004. PubMed PMID: 22633836. [PubMed: 22633836]

46. Imperiale TF, McCullough AJ. Do corticosteroids reduce mortality from alcoholic hepatitis? A meta-analysis of the randomized trials. Ann Intern Med. 1990; 113(4):299-307. PubMed PMID: 2142869. [PubMed: 2142869]

47. Akriviadis E, Botla R, Briggs W, Han S, Reynolds T, Shakil O. Pentoxifylline improves short-term survival in severe acute alcoholic hepatitis: A double-blind, placebo-controlled trial. Gastroenterology. 2000; 119(6):1637-48. doi: 10.1053/gast.2000.20189. [PubMed: 11113085]

48. Sidhu SS, Goyal O, Singla M, Bhatia KL, Chhina RS, Sood A. Pentoxifylline in severe alcoholic hepatitis: a prospective, randomised trial. J Assoc Physicians India. 2012; 60:20-2. PubMed PMID: 23029716.

49. De BK. Pentoxifyllineversusprednisolone for severe alcoholic hepatitis: A randomized controlled trial. World Journal of Gastroenterology. 2009; 15(13):1613. doi: 10.3748/wjg.15.1613. [PubMed: 19340904]

50. Whitfield K, Rambaldi A, Wetterslev J, Gluud C. Pentoxifylline for alcoholic hepatitis. Cochrane Database Syst Rev. 2009; (4):CD007339. doi: 10.1002/14651858.CD007339.pub2. PubMed PMID: 19821406. [PubMed: 19821406] 
51. Parker R, Armstrong MJ, Corbett C, Rowe IA, Houlihan DD. Systematic review: pentoxifylline for the treatment of severe alcoholic hepatitis. Aliment Pharmacol Ther. 2013; 37(9):845-54. doi: 10.1111/apt.12279. PubMed PMID: 23489011. [PubMed: 23489011]

52. Sidhu SS, Goyal O, Singla P, Gupta D, Sood A, Chhina RS, Soni RK. Corticosteroid plus pentoxifylline is not better than corticosteroid alone for improving survival in severe alcoholic hepatitis (COPE trial). Digestive diseases and sciences. 2012; 57(6):1664-71. doi: 10.1007/ s10620-012-2097-4. PubMed PMID: 22388710. [PubMed: 22388710]

53. Singh S, Murad MH, Chandar AK, Bongiorno CM, Singal AK, Atkinson SR, Thursz MR, Loomba R, Shah VH. Comparative Effectiveness of Pharmacological Interventions for Severe Alcoholic Hepatitis: A Systematic Review and Network Meta-analysis. Gastroenterology. 2015; 149(4):95870. e12. doi: 10.1053/j.gastro.2015.06.006. PubMed PMID: 26091937. [PubMed: 26091937]

54. Mezey E, Potter JJ, Rennie-Tankersley L, Caballeria J, Pares A. A randomized placebo controlled trial of vitamin E for alcoholic hepatitis. Journal of Hepatology. 2004; 40(1):40-6. doi: 10.1016/ s0168-8278(03)00476-8. [PubMed: 14672612]

55. Stewart S, Prince M, Bassendine M, Hudson M, James O, Jones D, Record C, Day CP. A randomized trial of antioxidant therapy alone or with corticosteroids in acute alcoholic hepatitis. $\mathrm{J}$ Hepatol. 2007; 47(2):277-83. doi: 10.1016/j.jhep.2007.03.027. PubMed PMID: 17532088. [PubMed: 17532088]

56. Nguyen-Khac E, Thevenot T, Piquet MA, Benferhat S, Goria O, Chatelain D, Tramier B, Dewaele F, Ghrib S, Rudler M, Carbonell N, Tossou H, Bental A, Bernard-Chabert B, Dupas JL, Group ANS. Glucocorticoids plus N-acetylcysteine in severe alcoholic hepatitis. The New England journal of medicine. 2011; 365(19):1781-9. doi: 10.1056/NEJMoa1101214. PubMed PMID: 22070475. [PubMed: 22070475]

57. Felver ME, Mezey E, McGuire M, Mitchell MC, Herlong HF, Veech GA, Veech RL. Plasma tumor necrosis factor alpha predicts decreased long-term survival in severe alcoholic hepatitis. Alcoholism, clinical and experimental research. 1990; 14(2):255-9. PubMed PMID: 2190492.

58. McClain CJ, Cohen DA. Increased tumor necrosis factor production by monocytes in alcoholic hepatitis. Hepatology. 1989; 9(3):349-51. PubMed PMID: 2920991. [PubMed: 2920991]

59. Spahr L, Rubbia-Brandt L, Frossard JL, Giostra E, Rougemont AL, Pugin J, Fischer M, Egger H, Hadengue A. Combination of steroids with infliximab or placebo in severe alcoholic hepatitis: a randomized controlled pilot study. J Hepatol. 2002; 37(4):448-55. PubMed PMID: 12217597. [PubMed: 12217597]

60. Menon KVN, Stadheim L, Kamath PS, Wiesner RH, Gores GJ, Peine CJ, Shah V. A Pilot Study of the Safety and Tolerability of Etanercept in Patients with Alcoholic Hepatitis. The American journal of gastroenterology. 2004; 99(2):255-60. doi: 10.1111/j.1572-0241.2004.04034.x. [PubMed: 15046213]

61. Boetticher NC, Peine CJ, Kwo P, Abrams GA, Patel T, Aqel B, Boardman L, Gores GJ, Harmsen WS, McClain CJ, Kamath PS, Shah VH. A randomized, double-blinded, placebo-controlled multicenter trial of etanercept in the treatment of alcoholic hepatitis. Gastroenterology. 2008; 135(6):1953-60. doi: 10.1053/j.gastro.2008.08.057. PubMed PMID: 18848937; PMCID: 2639749. [PubMed: 18848937]

62. Naveau S, Chollet-Martin S, Dharancy S, Mathurin P, Jouet P, Piquet MA, Davion T, Oberti F, Broet P, Emilie D, Foie-Alcool group of the Association Francaise pour l'Etude du F. A doubleblind randomized controlled trial of infliximab associated with prednisolone in acute alcoholic hepatitis. Hepatology. 2004; 39(5):1390-7. doi: 10.1002/hep.20206. PubMed PMID: 15122768. [PubMed: 15122768]

63. Louvet A, Wartel F, Castel H, Dharancy S, Hollebecque A, Canva-Delcambre V, Deltenre P, Mathurin P. Infection in patients with severe alcoholic hepatitis treated with steroids: early response to therapy is the key factor. Gastroenterology. 2009; 137(2):541-8. doi: 10.1053/j.gastro. 2009.04.062. PubMed PMID: 19445945. [PubMed: 19445945]

64. Altamirano J, Fagundes C, Dominguez M, Garcia E, Michelena J, Cardenas A, Guevara M, Pereira G, Torres-Vigil K, Arroyo V, Caballeria J, Gines P, Bataller R. Acute kidney injury is an early predictor of mortality for patients with alcoholic hepatitis. Clinical gastroenterology and hepatology : the official clinical practice journal of the American Gastroenterological Association.

Clin Gastroenterol Hepatol. Author manuscript; available in PMC 2018 January 01. 
2012; 10(1):65-71. e3. doi: 10.1016/j.cgh.2011.09.011. PubMed PMID: 21946124. [PubMed: 21946124]

65. Safi W, Rauscher I, Umgelter A. Contrast-induced acute kidney injury in cirrhotic patients. A retrospective analysis. Ann Hepatol. 2015; 14(6):895-901. doi: 10.5604/16652681.1171779. PubMed PMID: 26436362. [PubMed: 26436362]

66. Mendenhall CL, Moritz TE, Roselle GA, Morgan TR, Nemchausky BA, Tamburro CH, Schiff ER, McClain CJ, Marsano LS, Allen JI, et al. Protein energy malnutrition in severe alcoholic hepatitis: diagnosis and response to treatment. The VA Cooperative Study Group \#275. JPEN J Parenter Enteral Nutr. 1995; 19(4):258-65. PubMed PMID: 8523623. [PubMed: 8523623]

67. Cabre E, Rodriguez-Iglesias P, Caballeria J, Quer JC, Sanchez-Lombrana JL, Pares A, Papo M, Planas R, Gassull MA. Short- and long-term outcome of severe alcohol-induced hepatitis treated with steroids or enteral nutrition: a multicenter randomized trial. Hepatology. 2000; 32(1):36-42. doi: 10.1053/jhep.2000.8627. PubMed PMID: 10869286. [PubMed: 10869286]

68. Moreno C, Deltenre P, Senterre C, Louvet A, Gustot T, Bastens B, Hittelet A, Piquet MA, Laleman W, Orlent H, Lasser L, Serste T, Starkel P, De Koninck X, Negrin Dastis S, Delwaide J, Colle I, de Galocsy C, Francque S, Langlet P, Putzeys V, Reynaert H, Degre D, Trepo E. Intensive Enteral Nutrition Is Ineffective for Patients With Severe Alcoholic Hepatitis Treated With Corticosteroids. Gastroenterology. 2016; 150(4):903-10. e8. doi: 10.1053/j.gastro.2015.12.038. PubMed PMID: 26764182. [PubMed: 26764182]

69. Mohammad MK, Zhou Z, Cave M, Barve A, McClain CJ. Zinc and liver disease. Nutr Clin Pract. 2012; 27(1):8-20. doi: 10.1177/0884533611433534. PubMed PMID: 22307488. [PubMed: 22307488]

70. Li F, Duan K, Wang C, McClain C, Feng W. Probiotics and Alcoholic Liver Disease: Treatment and Potential Mechanisms. Gastroenterol Res Pract. 2016; 2016:5491465. doi: 10.1155/2016/5491465. PubMed PMID: 26839540; PMCID: PMC4709639. [PubMed: 26839540]

71. Mathurin P, Moreno C, Samuel D, Dumortier J, Salleron J, Durand F, Castel H, Duhamel A, Pageaux GP, Leroy V, Dharancy S, Louvet A, Boleslawski E, Lucidi V, Gustot T, Francoz C, Letoublon C, Castaing D, Belghiti J, Donckier V, Pruvot FR, Duclos-Vallee JC. Early liver transplantation for severe alcoholic hepatitis. The New England journal of medicine. 2011; 365(19):1790-800. doi: 10.1056/NEJMoa1 105703. PubMed PMID: 22070476. [PubMed: 22070476]

72. Addolorato G, Bataller R, Burra P, DiMartini A, Graziadei I, Lucey MR, Mathurin P, O'Grady J, Pageaux G, Berenguer M. Liver Transplantation for Alcoholic Liver Disease. Transplantation. 2016; 100(5):981-7. doi: 10.1097/TP.0000000000001156. PubMed PMID: 26985744. [PubMed: 26985744]

73. Chedid A, Mendenhall CL, Gartside P, French SW, Chen T, Rabin L. Prognostic factors in alcoholic liver disease. VA Cooperative Study Group. The American journal of gastroenterology. 1991; 86(2):210-6. PubMed PMID: 1992635. [PubMed: 1992635] 


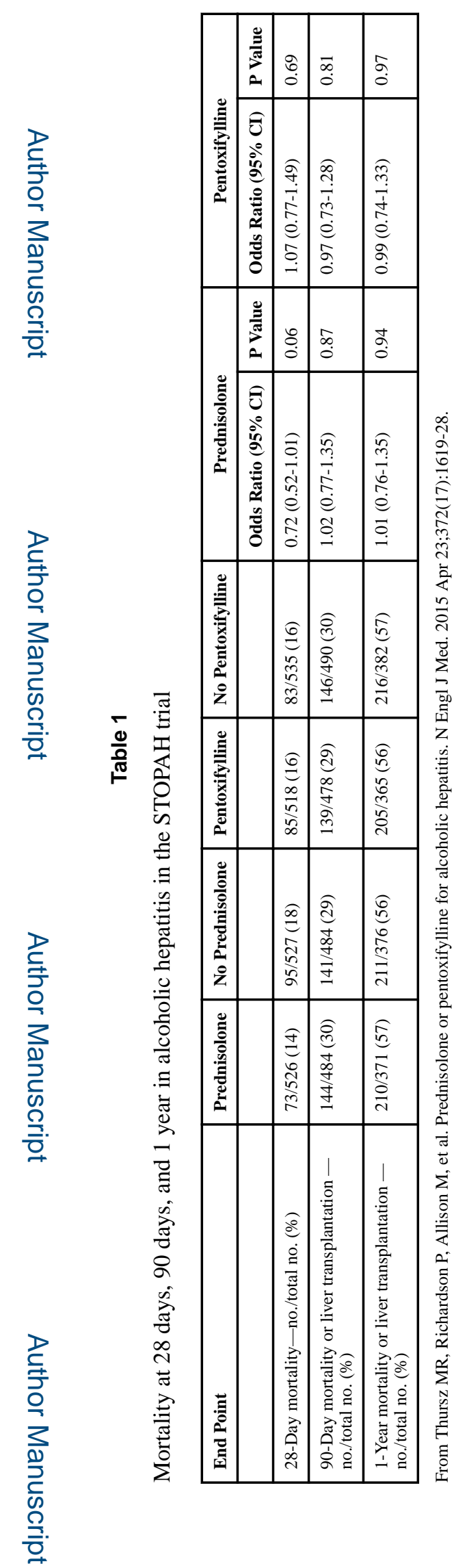

Clin Gastroenterol Hepatol. Author manuscript; available in PMC 2018 January 01. 
Table 2

Current recommendations for the diagnosis and treatment of acute alcoholic hepatitis (AH)

\begin{tabular}{|c|c|}
\hline Disease/condition & Acute $\mathrm{AH}$ \\
\hline Target audience & $\begin{array}{l}\text { Gastroenterologists, hepatologists, primary care physicians, emergency medicine physicians, and other } \\
\text { clinicians. }\end{array}$ \\
\hline Target patient population & $\begin{array}{l}\text { Adults with rapid onset of jaundice and elevated serum AST levels and a history of drinking more than } 40 \mathrm{~g} \\
\text { ( } 3 \text { standard drinks) of ethanol daily for more than } 1 \text { year. }\end{array}$ \\
\hline Criteria for diagnosis & $\begin{array}{l}\text { Onset of jaundice within } 8 \text { weeks of last period of drinking } \\
\text { Heavy drinking }(>40 \mathrm{~g} / \mathrm{day}) \text { for more than } 6 \text { months, usually for many years } \\
\text { Serum bilirubin }>3.0 \mathrm{mg} / \mathrm{dL} \\
\text { Serum AST }>50 \mathrm{IU} / \mathrm{L} \text { but }<400 \mathrm{IU} / \mathrm{L} \\
\text { Serum AST/ALT ratio }>1.5 \\
\text { Liver biopsy specimen showing macrovesicular steatosis, neutrophil infiltration, ballooning degeneration of } \\
\text { hepatocytes, megamitochondria, and Mallory-Denk bodies is helpful but not required for the clinical } \\
\text { diagnosis. }\end{array}$ \\
\hline Assessing severity & $\begin{array}{l}\text { Laboratory parameters are more reliable predictors of severe disease than clinical symptoms or signs or } \\
\text { imaging criteria. } \\
\text { Mathematical equations combining INR (prothrombin time) and serum bilirubin }+/- \text { creatinine, }+/- \text { age }+/- \\
\text { WBC count are effective tools } \\
\text { Maddrey discriminant function (MDF) }>32 \text { predicts high mortality within } 28 \text { days. } \\
\text { MELD score }>20 \text { predicts a high mortality rate within } 90 \text { days. } \\
\text { ABIC score category C predicts high } 28 \text { - and } 90 \text {-day mortality rates. } \\
\text { Glasgow alcoholic hepatitis score of } 9 \text { predicts a high } 28 \text {-day mortality rate. }\end{array}$ \\
\hline $\begin{array}{l}\text { Importance of recognition } \\
\text { and treatment }\end{array}$ & $\begin{array}{l}\text { Onset of jaundice indicates decompensation and is an ominous sign in all patients with chronic liver disease, } \\
\text { particularly those with alcoholic liver disease. } \\
\text { Although the name suggests a process that develops acutely, the majority of patients with AH have cirrhosis } \\
\text { at the time of diagnosis of AH. } \\
\text { Without treatment and abstinence from drinking alcohol, the mortality rate within } 90 \text { days is } 40-50 \% \text {. }\end{array}$ \\
\hline $\begin{array}{l}\text { Challenges related to } \\
\text { treatment }\end{array}$ & $\begin{array}{l}\text { The immune response, particularly neutrophil function, is impaired in patients with } \mathrm{AH} \text {, placing them at risk } \\
\text { of further decompensation following bacterial and fungal infections. } \\
\text { Many treatments for AH focus on reducing inflammation through use of glucocorticoids or other drugs that } \\
\text { suppress the immune system. } \\
\text { Failure to maintain abstinence from drinking alcohol may lead to further deterioration in liver function. }\end{array}$ \\
\hline Best Practice Advice (BPA) & 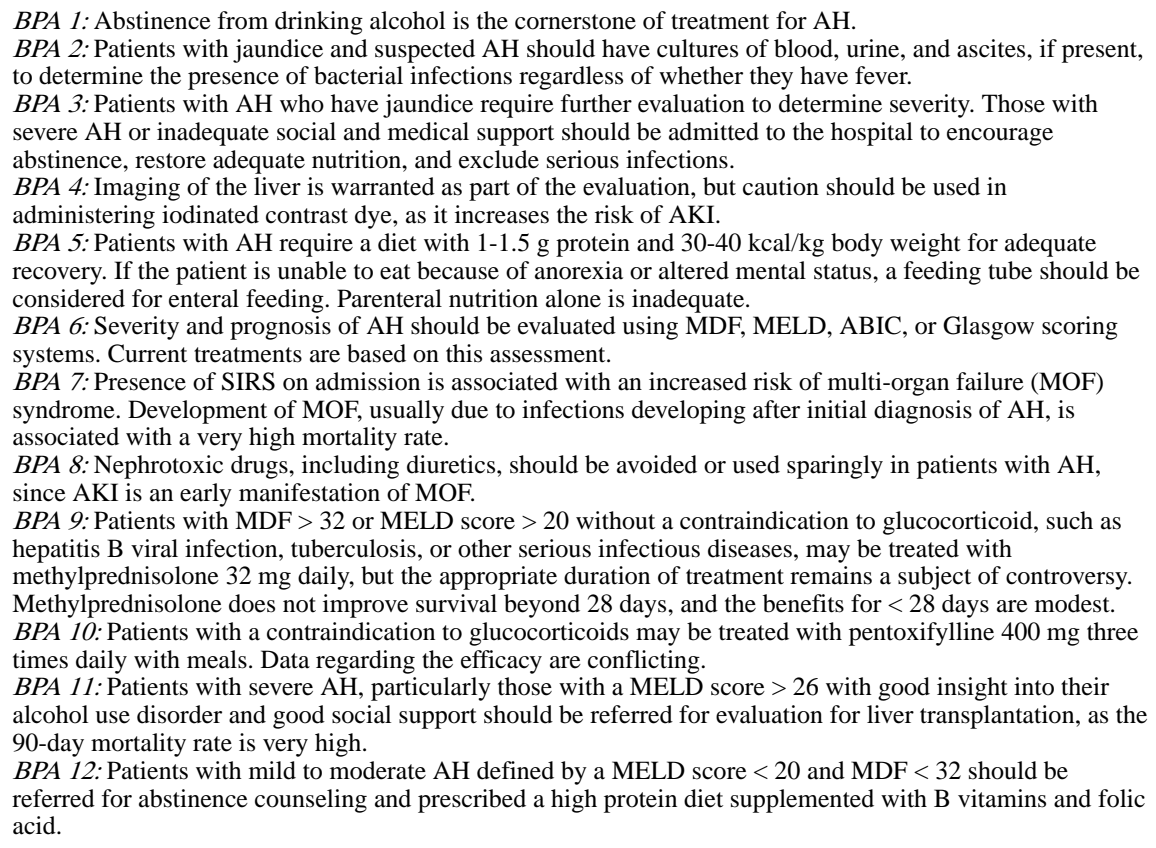 \\
\hline $\begin{array}{l}\text { Important points to discuss } \\
\text { with patients }\end{array}$ & $\begin{array}{l}\text { Patients should be encouraged to abstain completely from drinking but offered support and encouragement } \\
\text { even if they fail to achieve abstinence, as a reduction in alcohol consumption improves survival. }\end{array}$ \\
\hline
\end{tabular}


Adequate nutrition, including calories and protein, is necessary for recovery from $\mathrm{AH}$.

Patients who drink alcohol at hazardous levels ( $>40 \mathrm{~g} /$ day) should be advised to report jaundice as soon as it develops, since this symptom is a harbinger of serious injury.

ABIC, age, bilirubin, INR, creatinine; AKI, acute kidney injury; ALT, alanine aminotransferase; AST, aspartate aminotransferase; INR, international normalized ratio; MELD, Model for End-stage Liver Disease; SIRS, systemic inflammatory response syndrome; WBC, white blood cell. 